DOI: $10.31866 / 2410-1915.21 .2020 .208256$

UDC 793.3"195/20"

\title{
BACHATA AS A DANCE FORM: PERFORMANCE AND PECULIARITIES OF ARTISTIC IMAGE
}

\author{
Roman Hrytseniuk
}

Honoured Worker of Ukraine, Associate Professor, ORCID: 0000-0002-5361-7210, flashrivnedance@ukr.net, Rivne State University of Humanities, Rivne, Ukraine, 31, Plastova St., Rivne, 33000, Ukraine

\section{For citations:}

Hrytseniuk, R. (2020). Bachata as a Dance Form Performance and Peculiarities of Artistic Image. Culture and Arts in the Modern World, 21, 201-209. https://doi.org/10.31866/2410-1915.21.2020.208256.

The purpose of the article is to identify the features of the bachata social dance as a popular modern dance form; to analyse the stylistic features and the specifics of the technique of performance. Through the research, the historical method is to study the origin and popularisation of the dance; the typological approach is to identify the factors of dance formation and evolution, the features of transformative processes. In order to provide the background to the leading recent trends in social dance forms, the method of artistic and stylistic analysis is used; the method of artistic analysis is aimed at identifying the specific stylistic elements of bachata as a social and competitive dance.

In Ukrainian art studies, the bachata dance is studied as a social, cultural and artistic phenomenon for the first time ever; the process of formation and development of this dance form in retrospect is considered; the stylistic features of Dominican bachata, Western "traditional" bachata, modern bachata, sensual bachata and the specifics of its performance technique in the world-class competitions ("Sobre Todo 2019", "BachataStars Italy 2019", "Paris Bachata Festival Contest 2019”, Bachatastars International Champions, etc.) are defined. Specific features of bachata as a social dance form are shown in the specifics of the dance symbolism, the extreme flexibility and plasticity of performance. The study revealed the characteristic features of modern bachata styles: the quick tempos of performance, number of footwork, lack of lifts and rotations (authentic style); closed position, a close tie between dance couple, soft hip movements, wise set of turns and figures, borrowing movements and elements of ballroom dance styling (Western style); a combination of elements of Western bachata, salsa, tango and ballroom dancing, the dominance of body and hip movements (modern style); improvisation, a large variety of figures, the presence of lifts and elements of the show, elegant dress (sensual style).

Keywords: bachata; social dances; dance styling; stylistic features.

\section{Introduction}

The bachata style, which originated in the Dominican Republic in the second half of the twentieth century, is ubiquitous in most countries of the world 
as an expressive social dance. At the present stage, having developed in several directions, bachata is one of the most popular competitive, social and stage dances.

The scientific novelty is to study the bachata dance as a social, cultural and artistic phenomenon for the first time ever; to consider the process of formation and development of this dance form in retrospect; to define the stylistic features of Dominican bachata, Western "traditional" bachata, modern bachata, sensual bachata and the specifics of its performance technique in the world-class competitions ("Sobre Todo 2019" "BachataStars Italy 2019", "Paris Bachata Festival Contest 2019”, Bachatastars International Champions, etc.).

The development and transformation of social dance in the early $21^{\text {st }}$ century facilitated scientific research into the multi-faceted arts and cultural phenomenon. Many scientists have studied the problems of bachata dance at different stages. In particular, A. Tsurikov (2020) on the example of bachata examines the basic features of contemporary social dance as cultural phenomena; E. Lisina (2012) explores the question of ritual psychological and ontological meaning of social dancing in today's world; some aspects of the theory and practice of bachata as one of the most popular social dances clarified in scientific works B.Cohen-Stratyner (2001), C. Knolle (2008), J. Manrique Martínez and P. Ruiz-Montero (Manrique Martínez \& Ruiz-Montero, 2018) and others.

However, the technique and aesthetics specifics in the performance, the features of the dance art of bachata are issues that require thorough research and analysis in contemporary art studies terms.

\section{Purpose of the article}

The purpose of the article is to identify the features of bachata social dance as a popular contemporary dance form; to analyse the stylistic features and specifics of performance techniques.

Through the research, the historical method is to study the origin and popularisation of the dance; the typological approach is to identify the factors of dance formation and evolution, the features of transformative processes. In order to provide the background to the leading recent trends in social dance forms, the method of artistic and stylistic analysis is used; the method of artistic analysis is aimed at identifying the specific stylistic elements of bachata as a social and competitive dance.

\section{Main research material}

In the $20^{\text {th }}$ century, bursts of the popularity of various genres of Latin American couple dance in both the United States and Europe reinforcing the type of Latin American exotica, which at the present stage is taking on new development. Borrowing the style and elements of dance styling, rhythms, and musical accompaniment of folk dances, American and British dancers created new styles of performance of social and ballroom dances (Bosse, 2008, p. 45). 
Unlike many phenomena of modern mass culture, social dances are not of North American, but Latin American origin. According to researchers, the popularity of social dances at the present stage is largely due to the desire to challenge the disciplinary artistic ideals formed and spread by Western culture - the Caribbean, Cuban, Brazilian, Dominican and similar rhythms connected implicitly with a revolutionary spirit and traditions of a carnival, that is the celebratory ritual action having transcultural genesis, respectively, is a ritualised practice of modernity (Lisina, 2012, pp. 9-10). In particular, Sh. Bock and K. Borland (2011) argue that "dancers meaning invoke exotic cultures to create alternative ideals through dance experiences that open up opportunities for alternative self-expression" (p. 6).

Bachata is a form of the national cultural heritage of the Dominican Republic; a hybrid dance rhythm that originated from Bolero (Manrique Martínez \& Ruiz-Montero, 2018, p. 40); a musical style and dance (in 4/4 time), characterised by a moderato tempo and remarkable romantic lyrics dedicated to the theme of suffering from one-sided love and different life troubles, has become widespread in the Caribbean and most Latin American communities in the United States.

C. Knolle argues that historically bachata arose in the 1960s as a result of increased migration, urbanisation, and industrialisation in Latin America. Dominicans who migrated to the city, faced with economic exploitation, social discrimination and other problems of the common people, introduced a new style of music and dance (Knolle, 2008, p. 132). D. Manrique Martínez and P. Ruiz-Montero (2018) also define the bachata music rhythm as "a consequence of the emigration of large masses of peasants to the city, heard by lower military personnel and citizens with low economic status in brothels and popularised in the urban environment" (p. 42). Bachata was performed in the language of the local singer and reflected the culture and experience of the country's marginal population.

An early bachata was inspired by the slow romantic Cuban Bolero, known as "Bachatas románticas" or Bolero bachata. The typical music and dance, performed only in a close hold, often in a tight embrace, could not be better expressed the suffering and alienation of the poor, although the first, the so-called poetic bachata, were devoted exclusively to the theme of love. The basic step of the bachata, borrowed from the Bolero and transformed to include touches and syncopation in accordance with the dynamics of the musical accompaniment, was performed by moving within a small square. The hand placement varied with dance position - can be very close to semi-close to open (Knolle, 2008, p. 133).

K. Blossom claims that until the early 1970s in the Dominican Republic the word "bachata" (of African origin) was used to show disrespect to the followers of some style of music, as it was considered to belong to the "lower" class, uneducated, rude, vulgar and immoral. Initially, the term "bachata" was used to refer to "backyard parties" organised by the poorest rural migrants. Only since the 1970s bachata has been involved in the rich tradition of Latin American guitar music, becoming socially acceptable and accessible to the general public (Blossom, 2019, p. 7). 
Analysing the specifics of the music of bachata style, D. Pacini (1989) focuses on its inherent set of features that contribute to the definition of the genre: guitar-centred ensemble, sentimental themes, unfilled singing style, spoken language and low social status of both performers and audience (p. 5).

Those who practised the bachata dance style in the 1970s were predominantly of African-American origin. Still, because the Dominican Republic denied its African heritage, bachata was positioned as a dance of the poor, rather than as a form of "black music and dances" (Pacini Hernandez, 2014, p. 1030).

Bachata's international success was brought by the singer J. Guerra, who enriched it with tonally modernised synthesiser and electric guitar sounds (Wicke et al., 1997, p. 41). The thematic focus of bachata is also significantly expanded - in addition to love, gender issues are being updated (a woman belongs to the world of nature, and a person is part of the cultural world) and problems of relationships in a couple (the theme of sexual desire, female cheating, loneliness and separation); the romance of songs increasingly express frustration, anger and strong feelings between a man and a woman.

At the present stage, the style of authentic bachata (or Dominican bachata), which was created by Dominican social dancers for decades, continues to improve, remaining one of the most popular. Minor changes due to the evolution of the style are faster music; more footwork, simple turns and rhythmic freestyle moves; alternate between open and close position in a couple (Tsurikov, 2020, p. 101). The specifics of performing this style are soft hip movements and tap or syncopation (1,2, 3, touch/syncopation); it can be danced with or without a bounce also, moving the body up and down in between the beats by springs the legs a little.

C. Knolle (2008) claims that until the early 1990s bachata caused negative associations - music was played only in poor bars and on the poorest radio stations, but soon the music industry discovered the commercial potential of the style: additional instruments enriched the rhythm of bachata, the acoustic guitar was replaced with electric, the language, lyrics and metaphors changed, and thanks to the performance of famous professional musicians, its social status significantly increases (p. 132). Bachata lost its reputation as a vulgar style of lower-class music and dance associated with "poverty, crime and prostitution" (Pacini Hernandez, 1995, p. 158). It gained recognition as an autochthonous form of urban folk music (Knolle, 2008, p. 135).

The social profile of bachata dance is beginning to change due to its spread in New York by immigrants from the Dominicans in the 1990s - having lost its low-class affiliation, and bachata becomes "a powerful sound and plastic symbol of the Dominican homeland” (Pacini Hernandez, 2014, p. 1032).

Under socio-cultural and cultural-artistic transformations in the urban environment of South America, dancers and social dance teachers form a new style of bachata performance - Western bachata (Bachata Fusion or Traditional Bachata), the styling and manner of which differs from the authentic ones. Instead of the basic step of authentic bachata, there is a new step - move side to side, changing the direction after every tap. Characteristics of the dance are close hold; a close connection between dance partners; soft hip movements; 
the control point of the lady is the inner part of the hip that contacts the right leg of the man, and the man's hand on the lumbar spine with which he controls and directs the lady; and it does not include many turns and figures. Most of the styling in this dance is from ballroom dances and moves that are commonly used in social dances (Tsurikov, 2020, p. 101).

The beginning of the 2000s had a significant impact on the evolution of bachata dance styles. Spanish dancers K. Escalona and J. Cordero created the Bachata Sensual Style, which is based on the basic step and music of bachata, and among the characteristic features there are:

- individual interpretation of the music;

- a wide variety of figures;

- availability of lifts and show elements;

- a close partners position;

- a more elegant leading, which dramatically increases the sensuality of the dance performance.

This style provides opportunities for dancers to express emotions and demonstrate performance techniques.

K. Escalona is the founder of the most famous bachata competition "BachataStars", in which participating couples must demonstrate improvisation using dance and music skills.

In 2005, on the basis of the main elements of Western Bachata, using elements of salsa, tango and ballroom dancing, the style of modern bachata was developed, the specificity of which is the dominance of movements of the body and hips. In the same year, the International Dance Organization (IDO) held the first Bachata World Championship in Bassano del Grappa (Italy) (Knolle, 2008).

Following the review of performances of the dance couple Candido \& Tamara the winners of "Sobre Todo 2019", Spain, "BachataStars Italy 2019", and "Paris Bachata Festival Contest 2019" competitions, we can determine the steps, movements and figures required for the performance of the Bachata Sensual Style:

- a basic bachata step (two additional steps to the side in an open and closed, full-contact or shadow position, which is performed from side to side or forward-backwards);

- a basic, a 360 degree turn from a close hold on two closes to the right or left in different positions (a turn of both partners or a turn of the lady under the hand of the man only are allowed);

- an ocho hip movement in place;

- steps to the side with the stand and turning the body are performed in beats to music;

- a basic step with the raising of the arms (the half-moon path) is performed in a closed and shadow position;

- a basic step with putting hands over the head simultaneously (from an open position, the man, holding the lady's hands, puts them around the neck and performs the round movement of the head);

- basic movement from/to each other cornerwise - in an open or shadow position, partners perform steps as in the basic movement - forward-backwards cornerwise; 
- basic turn of the lady without breaking the hands and continuing to move in the shadow position - the man turns the lady under the hand, as if "twisting", and then they perform the figure of the Campana;

- a 180-degree turn of the lady left from the closed position into the shadow ones: the man leads the lady with his right hand bottom-upwards, both partners are turning their bodies following the hand; on beat " 2 " the man raises his arm upwards; on beat " 3 " he returns the lady on the left (her right hand is raised up); on beat "4" the man puts an arm around the lady's waist in shadow position;

- a back-bending by the lady: from a closed or full-contact position, the man touches the lady's shoulder with his left hand; she performs a tilt with the bodyweight transfer from the right leg to the left; when performing the tilt, both partners bend their knees;

- wave movement of the lady's body and hips;

- rotation of both partners in a closed position.

In addition to the "BachataStars" competition, in the world there are competitions, championships and festivals as "Das Bachata", "Paris Bachata Festival", "Bachata Festival Hamburg", "Hot Winter in Siberia"; Bachata is an obligatory dance discipline of the Couple Dance European Championship "Salsa, Bachata, Argentine Tango and Caribbean Dances".

Bachata is characterised by artistic reflection, means of rhythm plastic of body movements in space and time, which creates a particular type of styling.

The characteristic features of bachata dance (of any style) include:

- soft and relaxed manner of performance (no force is used in the leading, complex steps, techniques and virtuoso movements are not used);

- "intimate" performance (no wide steps and no a lot of space);

- holding a rhythm and musicality of performance;

- sensuality (the main driving force of dance is feelings and emotions);

- sexuality - the performance features provide for an extraordinary closeness of dance partners, which gives bachata intimacy, and researchers receive the reason to judge it to be as one of the most sexual social dances.

\section{Conclusions}

Features of bachata as a social dance are shown in the specifics of the dance symbolism (in deep grief hope for happiness is observed), a kind of plastic (the extreme flexibility and plasticity of performance, particularly of professional dancers) and dance performers' individualities (implemented due to the improvisational nature of the dance). The sensuality of dance movements is determined by the sentimentality of the musical accompaniment - soft wave movements hide an extraordinary passion, and the dominance of the performers' body contact creates an exciting romantic image.

The dance styling and manner of performance of various styles of bachata dance differ according to individual national or regional characteristics, depending on the musical accompaniment and the performance environment (night clubs, dance floors, competition floors, stage). The study revealed the charac- 
teristic features of modern bachata styles: the quick tempos of performance, number of footwork, lack of lifts and rotations (authentic style); closed position, a close tie between dance couple, soft hip movements, wise set of turns and figures, borrowing movements and elements of ballroom dance styling (Western style); a combination of elements of Western bachata, salsa, tango and ballroom dancing, the dominance of body and hip movements (modern style); improvisation, a large variety of figures, the presence of lifts and elements of the show, elegant dress (sensual style). The direction for future research is a comprehensive study of the stylistic features of bachata as a popular modern social dance.

\section{References}

Blossom, K. (2019). Salsa, Santería y Bachata [Salsa, Santeria and Bachata]. https://www. academia.edu/36832135/Salsa_Santeria_y_Bachata [in Spanish].

Bock, Sh., \& Borland, K.(2011). Exotic Identities: Dance, Difference, and Self-fashioning. Journal of Folklore Research, 48, 1, 1-36 https://doi.org/10.2979/jfolkrese.48.1.1 [in English].

Bosse, J. (2008). Salsa Dance and the Transformation of Style: An Ethnographic Study of Movement and Meaning in a Cross-Cultural Context. Dance Research Journal, 40, 1, 45-64. https://doi.org/10.1017/S0149767700001364 [in English].

Cohen-Stratyner, B. (2001). Social Dance: Contexts and Definitions. Dance Research Journal, 33, 2, 121-124. https://doi.org/10.2307/1477809 [in English].

Knolle, C. (2008). Salsa, Merengue, Bachata und deren enormer Boom [Salsa, Merengue, Bachata and their enormous boom]. (Dissertation Doktor der Philosophie: A 092 236 352). Universität of Vienna, Wien [in German].

Lisina, E. (2012). Ontology of the cultural influence dance as a ritual. Контекст и рефлексия: философия о мире и человеке, 2-3, 9-19 [in English].

Manrique Martínez, J. A., \& Ruiz-Montero, P. J. (2018). Influencia del baile latino "Bachata" sobre la vida social y funcional en mayores [Influence of the Latin dance "Bachata" on social and functional life in older people]. Revista INFAD de Psicología. International Journal of Developmental and Educational Psychology, 4, 1, 39-48 [in Spanish].

Pacini Hernandez, D. (1989). Social Identity and Class in "Bachata" an Emerging Dominican Popular Music Latin American Music Review. Revista de Música Latinoamericana, 10, 1, 69-91. https://doi.org/10.2307/780383 [in English].

Pacini Hernandez, D. (1995). Bachata: A Social History of a Dominican Popular Music. Temple University Press [in English].

Pacini Hernandez, D. (2014). Urban Bachata and Dominican Racial Identity in New York. Cahiers d études africaines, 54(4), 1027-1054. https://doi.org/10.4000/ etudesafricaines.17927 [in English].

Tsurikov, A. N. (2020). Bachata - primer sovremennogo sotcialnogo tantca [Bachata is an example of modern social dance]. Simvol nauki, 1, 98-104 [in Russian].

Wicke, P., Ziegenrücker, K.-E., \& Ziegenrücker, W. (1997). Handbuch der populären Musik [Popular music manual]. Schott [in German]. 


\section{БАЧАТА ЯК ТАНЦЮВАЛЬНА ПРАКТИКА: ВИКОНАННЯ ТА СПЕЦИФІКА ХУДОЖНЬОЇ ОБРАЗНОСТІ}

\section{Гриценюк Роман Анатолійович}

Заслужений діяч мистецттв України, доцент, ORCID: 0000-0002-5361-7210, flashrivnedance@ukr.net, Рівненський державний гуманітарний університет, Рівне, Україна

Мета статті - виявити особливості соціального танцю бачата як популярної сучасної танцювальної практики; проаналізувати стилістичні особливості та специфіку техніки виконання. У процесі дослідження застосовано історичний метод, що посприяв дослідженню виникнення та популяризації танцю; типологічний метод - виявленню чинників формування та еволюціонування танцю, особливостей трансформаційних процесів. 3 метою обгрунтування провідних сучасних тенденцій соціальних танцювальних практик використано метод художньо-стилістичного аналізу; метод мистецтвознавчого аналізу спрямований на виявлення характерних стилістичних ознак бачати як соціального та конкурсного танцю.

Вперше у вітчизняному мистецтвознавстві досліджено бачату як соціальне, культурне та мистецьке явище; розглянуто процес формування та розвитку означеної танцювальної практики в історичній ретроспективі; виявлено та проаналізовано стилістичні ознаки домініканської бачати, західної бачати, сучасної бачати, чуттєвої бачати та специфіку техніки виконання останньої у конкурсних програмах спортивно-змагальних заходів світового рівня («Sobre Todo 2019», «BachataStars Italy 2019», «Paris Bachata Festival Contest 2019», Bachatastars International Champions та ін.). Особливості бачати як соціальної танцювальної практики проявляються у специфіці образності танцю, надзвичайній гнучкості та пластичності виконання. Дослідження виявило характерні ознаки сучасних стилів бачати: швидкий темп виконання, значна кількість рухів ногами, відсутність підтримок та обертань (автентичний стиль); закрита позиція, тісний зв’язок між танцювальними партнерами, плавні рухи стегон, раціональний добір поворотів та фігур, запозичення рухів та елементів танцювальної лексики бальних танців (західний стиль); поєднання елементів західної бачати, сальси, танго та бальних танців, домінування рухів корпусом та стегон (сучасний стиль); імпровізаційність, велике розмаїття фігур, наявність підтримок та елементів шоу, витончене ведення (стиль сенчуал).

Ключові слова: бачата; соціальні танці; танцювальна лексика; стилістичні особливості. 


\title{
БАЧАТА КАК ТАНЦЕВАЛЬНАЯ ПРАКТИКА: ИСПОЛНЕНИЕ И СПЕЦИФИКА ХУДОЖЕСТВЕННОЙ ОБРАЗНОСТИ
}

\author{
Гриценюк Роман Анатольевич
}

Заслуженный деятель искусств Украины, доцент, ORCID: 0000-0002-5361-7210, flashrivnedance@ukr.net, Ровенский государственный гуманитарный университет, Ровно, Украина

Цель статьи - выявить особенности социального танца бачата как популярной современной танцевальной практики; проанализировать стилистические особенности и специфику техники исполнения. В процессе исследования применен исторический метод, который помог исследованию возникновения и популяризации танца; типологический метод - выявлению факторов формирования и эволюционирования танца, особенностей трансформационных процессов. С целью обоснования ведущих современных тенденций социальных танцевальных практик использован метод художественно-стилистического анализа; метод искусствоведческого анализа направлен на выявление характерных стилистических признаков бачаты как социального и конкурсного танца.

Впервые в отечественном искусствоведении исследован танец бачата как социальное, культурное и художественное явление; рассмотрен процесс формирования и развития обозначенной танцевальной практики в исторической ретроспективе; выявлены и проанализированы стилистические признаки доминиканской бачаты, западной бачаты, современной бачаты, чувственной бачаты и специфика техники исполнения последней в конкурсных программах спортивно-соревновательных мероприятий мирового уровня («Sobre Todo 2019», «BachataStars Italy 2019», «Paris Bachata Festival Contest 2019», Bachatastars International Champions и др.). Особенности бачаты как социальной танцевальной практики проявляются в специфике образности танца, чрезвычайной гибкости и пластичности исполнения. Исследование выявило характерные признаки современных стилей бачаты: быстрый темп исполнения, значительное количество движений ногами, отсутствие поддержек и вращений (аутентичный стиль); закрытая позиция, тесная связь между танцевальными партнерами, плавные движения бедер, рациональный подбор поворотов и фигур, заимствования движений и элементов танцевальной лексики бальных танцев (западный стиль); сочетание элементов западной бачаты, сальсы, танго и бальных танцев, доминирование движений корпусом и бедер (современный стиль); импровизационность, большое разнообразие фигур, наличие поддержек и элементов шоу, изящное ведение (стиль сенчуал).

Ключевые слова: бачата; социальные танцы; танцевальная лексика; стилистические особенности. 